\title{
Gamma interferon levels among Bangladeshi children after measles vaccination
}

\author{
Sultana S, Tabassum S, Nessa A, Jahan M \\ Department of Virology, Bangabandhu Sheikh Mujib Medical University, Shahbag, Dhaka. \\ Email:sharmins34@yahoo.com
}

\begin{abstract}
Gamma interferon (IFN- $\gamma$ ) plays an important role in the immune response to live measles virus vaccination. To study the immune response to measles vaccination, IFN- $\gamma$ level was estimated in 30 children. Of these, 24 children vaccinated with a single dose of measles vaccine at nine months of age and 06 children vaccinated with a second dose during the Measles Catch-up Immunization campaign. Measles vaccine strain was cultured in Vero cell line and the Tissue Culture Infective Dose (TCID) $)_{50}$ was used as standard live virus. Peripheral blood Mononuclear cells (PBMCs) was separated by FicollHypaque density gradient centrifugation and stimulated with measles virus antigens and mitogens (lectin), cultured in $\mathrm{CO}_{2}$ and IFN- $\gamma$ level was measured from culture supernatant by ELISA. On stimulation with measles antigen and lectin respectively, IFN- $\gamma$ level was highest $(105 \mathrm{pg} / \mathrm{ml}$ and $226.54 \mathrm{pg} / \mathrm{ml})$ in the $109-120$ months age group while it was lowest $(12.97 \pm 8.16 \mathrm{pg} / \mathrm{ml}$ and $13.16 \pm 8.0$ $\mathrm{pg} / \mathrm{ml}$ ) in the 61-72 months age group. No significant difference was observed in IFN- $\gamma$ level after stimulation with either measles antigen or lectin among well-nourished $(\mathrm{p}<0.8)$ and mal-nourished $(\mathrm{p}<0.7)$ children suggesting that nutritional status did not have any effect on IFN- $\gamma$ level. However, IFN- $\gamma$ level was higher in children who received two dose of measles vaccine than those who received a single dose $(\mathrm{p}<0.001)$.
\end{abstract}

\section{Introduction}

Measles is a major cause of childhood morbidity and mortality especially among young children from developing countries like Bangladesh. In the absence of proper immunization programmes, it affects nearly every person in a given population by adolescence. $^{1}$ Measles vaccine induces both humoral immunity and cell mediated immune (CMI) responses. Humoral immunity to measles vaccine has been extensively studied, and it is believed that both primary vaccine failure (complete lack of antibody after immunization) and secondary vaccine failure (waning or insufficient antibody after immunization) may be responsible for the variable efficacy of measles vaccine. ${ }^{2-4}$ It is speculated that measles vaccine failure may result from the induction of a polarized cytokine profile, which induces an immune response that may not be sufficiently protective. ${ }^{5}$ Although humoral immunity plays a pivotal role in protection against measles, several reports suggest that CMI is essential for recovery from measles and may provide long-term immunity. ${ }^{6-9}$ This is best illustrated in children with isolated agammaglobulinemia who recover from measles and develop lifelong immunity. ${ }^{10}$ In contrast, individuals with T-cell deficiencies, such as, leukemia and human immunodeficiency virus (HIV) infection experience a progressive illness with $50-100 \%$ mortality. ${ }^{11-12}$ These findings clearly suggest that the cellular immune response plays a central role in immunity to measles infection and in protection against reinfection.

Despite the importance of cellular responses in measles, relatively little is known about the cellular immune response induced by measles vaccination. Subpopulation within the classical CD4+T lymphocyte subsets differ in the spectra of cytokines they produce when stimulated by antigens. ${ }^{13}$ The production of Th2 cytokines (IL-4, IL-5) by CD4+T lymphocytes is essential for the development of measles antibody production. ${ }^{9,14}$ Th1 cytokines (IFN- $\gamma$, IL-2) also affects both B and $\mathrm{T}$ cell functions and plays a significant role in the control and resolution of measles virus infection. ${ }^{15-17}$ Moreover, IFN- $\gamma$ is critical for macrophage activation, $\mathrm{T}$ cell proliferation and differentiation and for up-regulation of human leucocyte antigens. ${ }^{18-20}$ IFN- $\gamma$ exerts an antiviral effect by promoting the lysis and clearance of measlesinfected cells and by inhibiting viral gene expression and replication. ${ }^{17}$

The present study estimated IFN- $\gamma$ levels among measles vaccinated children aged 1-10 years who had received a single or in some cases double dose of measles vaccine. 


\section{Materials and Methods}

The study population consisted of 30 children selected according to specific selection criteria from the Vaccination Centre, Dept. of Virology, BSMMU. Of these, 24 children were vaccinated with one dose of measles vaccine at nine months of age according to the Expanded Program on Immunization (EPI) schedule, and 6 children were vaccinated with a second dose of measles vaccine during the Measles Catch-up Immunization Campaign. The relevant information and vaccination history from the study children were recorded in a standard pre-designed questionnaire/ data sheet by interviewing the guardians of the subjects. Informed written consent was taken from them before collection of blood samples.

For detection of IFN- $\gamma$ level, measles vaccine virus was cultured and titrated at the Institute of Public Health (IPH), Mohakhali, Dhaka. Briefly, $1.5 \times 10^{6}$ Vero cells in Dulbecco Minimum Essential Medium (DMEM) culture medium containing 5\% fetal calf serum was seeded into each of eight $75-\mathrm{cm}^{2}$ tissue culture flasks and incubated at $37^{\circ} \mathrm{C}$ in a $5 \% \mathrm{CO}_{2}$ humidified incubator until 70 to $80 \%$ confluent (approximately 3-4 days). Then, the Vero cells were infected with $3 \mathrm{~mL}$ of measles virus (Edmonston vaccine strain) and incubated at $37^{\circ} \mathrm{C}$ in a $5 \% \mathrm{CO}_{2}$ humidified incubator for 24-36 hour until the cells formed into an approximately 80-90\% syncytia. Titration of measles vaccine virus was done by using the Spearman-Karber method of 50\% tissue culture infective dose $\left(\mathrm{TCID}_{50}\right)$ and it was used as standard live virus. ${ }^{21}$

Fresh blood $(5 \mathrm{ml})$ was collected in heparin and peripheral mononuclear cells (PBMC) were separated by Ficoll-Hypaque density gradient centrifugation technique at the Dept. of Virology, BSMMU. PBMCs were stimulated with both measles virus antigens and mitogens (lectin). Stimulated PBMCs were cultured in $\mathrm{CO}_{2}$ incubator for 96 hours and IFN- $\gamma$ level was measured from the culture supernatant by ELISA technique using the Human IFN- $\gamma$ Quantikine Immunoassay (R\&D Systems).
Statistical analysis: Data were analyzed by using SSPS software 15.0. Unpaired t test was done as required.

\section{Results}

The levels of Interferon gamma (IFN- $\gamma$ ) secretion by peripheral blood mononuclear cells (PBMC) due to different types of stimulation in children of various age groups who received a single dose of measles vaccine observed that the level of IFN- $\gamma$ increased gradually with increasing age of the children. After stimulation with measles antigen, the IFN- $\gamma$ level was lowest $(12.97 \pm 8.16 \mathrm{pg} / \mathrm{ml})$ in the 13-24 months age group, and reached its highest $(105.00 \mathrm{pg} / \mathrm{ml})$ level in the $109-120$ months age group. Similarly, after lectin stimulation, the level of IFN- $\gamma$ was also observed to be lowest $(13.16 \pm 8.0$ $\mathrm{pg} / \mathrm{ml}$ ) in the 13-24 months age group, and also peaked $(226.54 \mathrm{pg} / \mathrm{ml})$ in the $109-120$ months age group (Fig 1).

Among the study children, 24 (80\%) children received a single dose of measles vaccine while 6 $(20 \%)$ children received two doses. After stimulation with measles antigen, the IFN- $\gamma$ level in children who received two doses of measles vaccine was significantly higher $(228.47 \pm 120.11 \mathrm{pg} / \mathrm{ml})$ than those who received one dose of vaccine $(62.38 \pm 50.51 \mathrm{pg} / \mathrm{ml}) \quad(\mathrm{p}<0.001)$. Similarly, after lectin stimulation, the IFN- $\gamma$ level in children who received two doses of measles vaccine was significantly higher $(184.5 \pm 80.90 \mathrm{pg} / \mathrm{ml})$ than those who received only one dose of vaccine $(69.85 \pm 45.14 \mathrm{pg} / \mathrm{ml})(\mathrm{p}<0.043)$ (Table I).

The association between nutritional status and IFN$\gamma$ level among the study population showed that the majority $27(90 \%)$ were well-nourished while 3 (10\%) were malnourished. After stimulation with measles antigen, IFN- $\gamma$ level secreted by PBMC was higher $(103.92 \pm 80.04 \mathrm{pg} / \mathrm{ml})$ in well-nourished than in malnourished $(94.67 \pm 50.14 \mathrm{pg} / \mathrm{ml})$ children $(\mathrm{p}<0.900)$. Similarly, after lectin stimulation, IFN $-\gamma$ level was higher $(120.10 \pm 90.05 \mathrm{pg} / \mathrm{ml})$ in wellnourished than in malnourished $(89.74 \pm 45.56$ $\mathrm{pg} / \mathrm{ml})$ children $(\mathrm{p}<0.698)$ (Table II).

Fig 1: Interferon gamma secretion by peripheral blood mononuclear cells (PBMC) by different types of stimulation in vaccinated children.

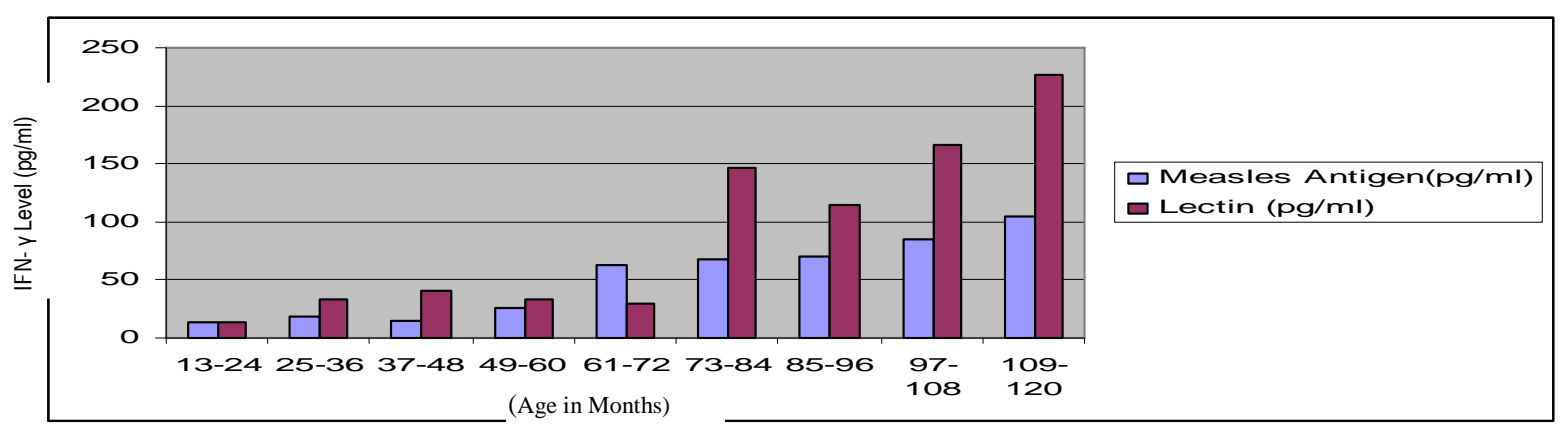


Table I: Association between numbers of doses of measles vaccine with level of Interferon- $\gamma$ after stimulation.

\begin{tabular}{ccccc}
\hline \multirow{2}{*}{$\begin{array}{c}\text { Number } \\
\text { of doses }\end{array}$} & $\begin{array}{c}\text { vumber of } \\
\text { children } \\
\end{array}$ & \multicolumn{3}{c}{$\begin{array}{c}\text { Mean }( \pm \text { SD) Interferon gamma level }(\mathrm{pg} / \mathrm{ml}) \\
\text { after stimulation with }\end{array}$} \\
\cline { 3 - 5 } & 24 & Measles Ag & Lectin & No stimulation \\
\hline 1 & $06.38 \pm 50.51$ & $69.85 \pm 45.14$ & $8.79 \pm 4.45$ \\
2 & $228.47 \pm 120.11$ & $184.51 \pm 80.90$ & $17.03 \pm 5.32$ \\
$\mathrm{P}$ value & & 0.001 & 0.043 & 0.237 \\
\hline Unpaired t test was done.
\end{tabular}

Table II: Association between nutritional status and IFN- $\gamma$ level after antigen stimulation.

\begin{tabular}{|c|c|c|c|c|}
\hline \multirow{2}{*}{$\begin{array}{l}\text { Nutritional } \\
\text { status }\end{array}$} & \multirow{2}{*}{$\begin{array}{l}\text { Number of } \\
\text { children } \\
(n=30)\end{array}$} & \multicolumn{3}{|c|}{$\begin{array}{l}\text { Mean }( \pm \text { SD) Interferon gamma level } \\
(\mathrm{pg} / \mathrm{ml}) \text { after stimulation with }\end{array}$} \\
\hline & & Measles Ag & Lectin & $\begin{array}{c}\text { No } \\
\text { stimulation }\end{array}$ \\
\hline Well nourished & 27 & $103.92 \pm 80.04$ & $120.10 \pm 90.5$ & $10.92 \pm 6.05$ \\
\hline Mal nourished & 03 & $94.67 \pm 50.14$ & $89.74 \pm 45.56$ & $06.08 \pm 4.10$ \\
\hline $\mathrm{P}$ value & & 0.900 & 0.698 & 0.607 \\
\hline
\end{tabular}

\section{Discussion}

The introduction of an effective live attenuated virus vaccine has dramatically reduced the incidence of measles. Despite this, measles has not been eliminated because of failure to vaccinate all children during the first year of life and also due to cases of vaccine failure. Since the introduction of live attenuated measles vaccines, a gradual decline in the level of measles antibodies over time after immunization has been described but no cases of measles has been reported during follow-up. ${ }^{22-26}$ These observations suggest that low titers of measles antibodies may be protective or that persistence of cellular immunity to measles may play an important role in preventing measles infection. Moreover, it has been established that individuals with sufficiently low antibody levels are at risk of mild or sub clinical measles infection. ${ }^{27}$ It is thus important to understand the host response to measles vaccination among children in order to provide effective protection during the first year of life.

Our study observed that IFN- $\gamma$ increased gradually with increasing age of children, being lowest in the 13-24 months age group and highest among 109120 months after stimulation with both measles antigen and lectin. Measles immunization leads to the development of a measles virus specific memory $\mathrm{T}$ cells that may sustained for a prolonged period after immunization.

Children who received two doses of measles vaccine had high IFN- $\gamma$ levels than those who received a single dose of measles vaccine. Although there are few precise data on the effect of a second dose of measles vaccination among children first immunized after one year of age, epidemiological studies show that increased protection is obtained after a second dose. ${ }^{28}$ In an outbreak investigation in the USA in 1985, attack rates were $30 \%-60 \%$ lower in children who received two doses of measles vaccine compared with single-dose vaccinees. ${ }^{29-30}$ This indicates that cell mediated immunity can be enhanced after a booster dose of measles vaccine given in the presence of high antibody titers. The cellular immune responses may be better sustained than antibody titers after vaccination and revaccination in some subjects. ${ }^{5}$

Malnutrtion can impair an individual's immune response to immunization with live attenuated vaccine like B.C.G, yellow fever, poliomyelitis vaccine. It may also affect the host response to measles vaccine. The impairment of some components of the immune system poses a theoretical possibility. Our study observed that the IFN- $\gamma$ level was comparatively higher in wellnourished children than malnourished children but this difference was not statistically significant. Other studies have reported profoundly impaired $\mathrm{T}$ cell function in human malnutrition. ${ }^{31-36}$ However, our study demonstrated that malnourished children responded adequately to measles vaccine.

It can be concluded from our study that IFN- $\gamma$ level increased with increasing age of children, with higher IFN- $\gamma$ level in children receiving a second dose of measles vaccine in comparison to children who received a single dose. Furthermore, our study did not observe any difference between malnourished and well-nourished children after measles antigen or lectin stimulation. Further extensive studies with larger sample size should be undertaken to detect IFN- $\gamma$ responses after measles vaccination in different age groups to confirm the findings of our study.

\section{References}

1. Black FL. The role of herd immunity in control of measles. Yale J Biol Med 1982; 55: 352-60.

2. Anders JF, Jacobson RM, Poland GA, Jacobsen SJ \& Wollan PC. Secondary failure rates of measles vaccines: A metaanalysis of published studies. Pediatr Infect Dis J 1996; 15: 62-6.

3. Markowitz LE \& Katz ML. Measles vaccine. In SA Plotkin and EA Mortimer Jr. (ed.) Vaccines 1994: 22976.

4. Orenstein WA, Herrmann K, Albrecht P, Bernier R, Holmgreen P, Bart KJ \& Hinman AR. Immunity against measles and rubella in Massachusetts school children. Dev Biol Stand 1986; 65: 75-83.

5. Ward BJ \& Griffin DE. Changes in cytokine production after measles virus vaccination: predominant production of IL-4 suggests induction of a Th-2 response. Clin Immunol Immunopathol 1993; 67: 171-7.

6. Gans H, Yasukawa L, Rinki M, DeHovitz R, Forghani B, Beeler J, Audet S, Maldonado Y \& Arvin AM. 
Immune responses to measles and mumps vaccination of infants at 6, 9 and 12 months. J Infect Dis 2001; 184: $817-26$.

7. Jaye A, Magnusen AF, Sadiq AD, Corrah A \& Whittle HC. Ex vivo analysis of cytotoxic T lymphocytes to measles antigens during infection and after vaccination in Gambian children. J Clin Investig 1998; 102: 196977.

8. Samb B, Aaby P, Whittle HC, Coll Seck AM, Rahman S, Bennett J, Markowitz L \& Simondon F. Serologic status and measles attack rates among vaccinated and unvaccinated children in rural Senegal. Pediatr Infect Dis 1995; 14: 203-9.

9. Ward BJ, Johnson RT \& Vaisberg A. Cytokine production in vitro and the lympho-proliferative defect of natural measles virus infection. Clin Immunol Immunopathol 1991; 61: 236-48.

10. Good RA, \& Zak SJ. Disturbance in gamma globulin synthesis as "experiment of nature". Pediatrics 1956; 18(1): 109-49.

11. Markowitz LE, Stephen RP, Orenstein WA, Elizabeth ZR, Stat M, Nancy CA, Hawkins CE, Hinmann AR. Patterns of transmission in measles out breaks in the United States, 1984-1985. N Engl J Med 1989; 320: 75-81.

12. Mitus A, Holloway A \& Enders JF. Attenuated measles vaccine in children with acute leukemia. Am J Dis Child 1965; 03: 413-18.

13. Street NE \& Mosmann TR. Functional diversity of T lymphocytes due to secretion of different cytokine patterns. Faseb J 1991; 5: 171-77.

14. Li H, Hickman CJ, Hefland RF, Keyserling H, Anderson LJ, Bellini WJ. Induction of cytokine mRNA in peripheral blood mononuclear cells of infants after the first dose of measles vaccine. Vaccine 2001; 19: 4896-4900.

15. Howard MC, Miyajima A \& Coffman R. T cell-derived cytokines and their receptors. In Fundamental Immunology New York: Raven Press 1993; 763-800.

16. Finke D, Brinckmann UG, Meulen VT \& Liebert UG. Gamma interferon is a mediator of antiviral defense in experimental measles virus-induced encephalitis. J Virol 1995; 69: 5469-74.

17. Scheneider SS, Liebert UG, Segev Y, Seirgaiv T. Antibody dependant transcriptional regulation of measles virus in persistently infected neural cells. J Virol 1992; 66: 5534-41.

18. Gogate N, Bakhiet M, Kristensson K, Norrby E, Olsson, $\mathrm{T}$. Gamma interferon expression and major histocompatibility complex induction during measles and vesicular stomatitis virus infections of the brain. $\mathbf{J}$ Neuroimmunol 1991; 31:19-26.

19. GoodbournS, Didcock L, Randall RE. Interferons: cell signaling, modulation, anti viral responses and virus countermeasures. J Gen Virol 2000; 81: 2341-64.

20. Paludon SR. Interleukin-4 and interferon- gamma: the quintessence of a mutual antagonistic relationship. Scand J Immunol 1998; 48: 459-68.
21. Jenna ER, Inna GO, Gregory P. Detection of Measles Virus-specific Interferon $\gamma$ Secreting $\mathrm{T}$ cells by ELISPOT. Methods in Molecular Biology 2005; 302: 207-18.

22. Markowitz LE, Prelub SR, Fine PEM \& Orenstein WA. Duration of live measles vaccine-induced immunity. Pediatr Infect Dis J 1990; 9: 101-10.

23. Markowitz LE, Albrecht P \& Orenstein WA. Persistence of measles antibody after revaccination. J Infect Dis 1992; 166: 205-8.

24 Christenson B \& Bottiger M. Measles antibody: comparison of long term vaccination titers and naturally acquired immunity to and booster effects on the measles virus. Vaccine 1994; 12:129-33.

25. Cohn M, Robinson E, Faerber M, Thomas D, Geyer S, Peter S, Martin M, Martin A, Sobel D \& Jones R. Measles vaccine failure: Lack of sustained measlesspecific immunoglobulin $\mathrm{G}$ responses in revaccinated adolescents and young adults. Pediatr Infect Dis J 1994; 13: 34-8.

26. Johnson CE, Kumar ML \& Whitwell JK. Antibody persistence after primary measles-mumps-rubella vaccine and response to a second dose given at four to six vs eleven to thirteen years. Pediatr Infect Dis J 1996; 15: 687-92.

27. Whittle HC, Aaby P, Samb B, Jensen H, Bennett J \& Simondon F. Effect of subclinical infection on maintaining immunity against measles in vaccinated children in West Africa. Lancet 1999; 353(9147):98102.

28. Ferguson AC, Lawlor GJ, Neumann CG \& Stiehm ER. Decreased rosette-forming lymphocytes in malnutrition and intrauterine growth retardation. J. Pediat 1974; 85: 717-23.

29. Schlesinger L, Stekel A. Impaired cellular immunity in marasmic infants. Am J Clin Nutr 1974; 27: 615-20.

30.World Health Organization, Geneva. The Immunological Basis for Immunization / Module 7: Measles. p 1-20.

31. Smythe PM, Schonland B, Coovadia HM, Grace HJ, Loening WE, Mafoyane A, Parent MA \& Vos GH. Thymolymphatic deficiency and depression of cell mediated immunity in protein-calorie malnutrition Lancet 1971; 2: 939-43.

32. Neumann CG, Lawlor GJ, Stiehm ER, Swenseid ME, Newton C, Herbert J, Ammann AJ \& Jacob M. Immunologic response in malnourished children. Am J Clin Nutr 1975; 28(2): 89-104.

33. Harland PSEG \& Brown RE. Tuberculin sensitivity following BCG vaccination in undernourished children. E African Med J 1965; 42: p 233.

34. Lloyd AVC. Tuberculin test in children with malnutrition. Brit Med J. 1968; 3: 529-31.

35. Sellmeyer E, Bhettay E, Truswell AS, Meyers OL \& Hansen JDL. Lymphocyte transformationin malnourished children. Arch Disease Childhood 1972; 47: $\mathrm{p} 429$.

36. Chandra RK. Immunoglobulins and antibody response in protein calorie malnutrition - a review. In: Mal nutrition and the Immune response). edited by $\mathrm{R}$. Suskind: New York. Raven Press 1977; p 155. 